\title{
Possible association between anti-Ro antibodies and myocarditis or cardiac conduction defects in adults with systemic lupus erythematosus
}

\author{
D Logar, T Kveder, B Rozman, J Dobovišek
}

\begin{abstract}
In view of the association of congenital heart block with maternal antibody to cellular antigen Ro (SSA), and one report linking anti-Ro with myocarditis in a patient with myositis an association between anti-Ro antibodies and cardiac disease was sought in adults with systemic lupus erythematosus (SLE). Among 67 patients with SLE, of whom 36 were antiRo positive, a significantly higher prevalence of myocarditis and conduction defects was found in the anti-Ro positive group (eight of 36) than in those who were anti-Ro negative (one of 31) and healthy controls (one of 50). Of the 36 anti-Ro positive patients with SLE, three had symptoms diagnostic of myocarditis, and an electrocardiogram showed first degree atrioventricular block and unifascicular block in three cases (including one with myocarditis), right bundle branch block alone (two cases), and first degree atrioventricular block alone (one case). Complete atrioventricular block was not seen. In the anti-Ro negative group there was no myocarditis and only one case of conduction defect (right bundle branch block). Among healthy controls only one of $\mathbf{5 0}$ had first degree atrioventricular block.

It is concluded that myocarditis and conduction defects are reasonably common in adults with SLE and are associated with antiRo antibodies.
\end{abstract}

The presence of anti-Ro (SSA) antibodies in adults with systemic lupus erythematosus (SLE) has been associated with different subsets of the disease, including subacute cutaneous lupus erythematosus, antinuclear antibody negative lupus, and the lupus like disease of homozygous $\mathrm{C} 2$ and $\mathrm{C} 4$ deficiency. ${ }^{1-3}$ Since the first report of myocardial disease in neonatal lupus erythematosus was published by McCuiston and Schoch in $1954^{4}$ several articles have reported the association between SLE and anti-Ro or anti-La autoantibodies and myocardial disease. ${ }^{5-12}$

Although Maier reported on a patient with SLE who had complete heart block as the first manifestation of the disease, ${ }^{13}$ the possible association between antibodies to Ro or La and myocarditis or heart conduction defects in adults with SLE remains unclear. The purpose of this study was to determine the following: (i) the association between the presence of anti-Ro autoantibodies and myocarditis or cardiac conduction defects in adults with SLE; and (ii) possible HLA markers in such patients with myocarditis or cardiac conduction defects.

\section{Materials and methods}

The serum samples of 67 patients with SLE from different areas of Yugoslavia were studied. There were 57 women and 10 men. All patients fulfilled the diagnostic criteria revised in $1982 .{ }^{14}$ Anti-Ro antibodies were found in 36 patients32 women and four men (age range 17-62 and 18-64 years, mean 37 and $37 \cdot 5$ years, respectively). The control group comprised 50 healthy adults - 38 women and 12 men (age range 16-71 and 16-68 years, mean 37 and 31 years, respectively).

The follow up periods of anti-Ro positive and anti-Ro negative patients were 4.5 and 5.8 years, respectively. Myocarditis was diagnosed according to the criteria of Wynne and Braunwald $^{15}$ and Borenstein, 16 with reference to clinical picture (dyspnoea, palpitations, tachycardia, S3 gallop, sudden congestive heart failure), chest $x$ ray (increased cardiothoracic ratio), electrocardiogram (ECG) changes (ventricular arrhythmias, non-specific ST-T wave changes, conduction defects), and echocardiogram changes (enlargement of the heart chamber, decreased left ventricular ejection fraction, ventricular wall/septal hypokinesia). The diagnostic criteria recommended by French and Crilley were also considered. ${ }^{17}$ Conduction defects were shown by the electrocardiogram.

Antinuclear antibodies were detected by an immunofluorescence technique and antibodies against dsDNA by the Farr assay using antigen marked with ${ }^{14} \mathrm{C} .{ }^{18}$ Antibodies against extractable nuclear antigens were determined by counterimmunoelectrophoresis as reported by Bunn et al. ${ }^{19}$ HLA typing was carried out by the microdroplet lymphocytotoxicity test. ${ }^{20} 21$

Serological findings and the results of clinical and cardiac examinations obtained on each visit to the department were processed on an IBM PC computer and tested for significance with the $\chi^{2}$ analysis using the statistical package for the social sciences (SPSS)/PC+ program.

\section{Results}

The group of 36 anti-Ro positive patients was divided into several subgroups according to the presence of other anti-extractable nuclear antigen antibodies. Eighteen patients had only anti-Ro antibodies and five had antibodies to Ro and La. We detected anti-Ro together with other autoantibodies to extractable nuclear antigens in 13 serum samples: U1-RNP in five; $\mathrm{Sm}$ in three; SL in two; and antibodies to unidentified antigens in five (table 1). Among anti-Ro negative patients, 22 were completely anti- 
Table 1: Association between presence of anti-Ro antibodies and incidence of myocarditis or cardiac conduction defects in 67 patients with systemic lupus erythematosus

\begin{tabular}{llll}
\hline Defects & $\begin{array}{l}\text { Number } \\
\text { of } \\
\text { patients }\end{array}$ & $\begin{array}{l}\text { Number of } \\
\text { patients with } \\
\text { myocarditis or } \\
\text { cardiac conduction } \\
\text { defects }\end{array}$ & p Value \\
\hline All Ro/Ro negative & $36 / 31$ & $8 / 1$ & $<0.01$ \\
All Ro/controls & $36 / 50$ & $8 / 1$ & $<0.01$ \\
\hline
\end{tabular}

extractable nuclear antigen negative, while in nine cases other antibodies to the following extractable nuclear antigens were detected: U1RNP in one; Sm in one; PL-4 in two, SL in one; proliferating cell nuclear antigen (PCNA) in one; and unidentified antigens in four.

Conduction defects or myocarditis (table 2) were found in eight of $36(22 \%)$ patients of the anti-Ro positive group, compared with one of 31 anti-Ro negative patients $(p<0.01)$, and one of 50 controls $(\mathrm{p}<0.01)$.

Clinical details of the three cases with myocarditis were as follows. One 55 year old woman had an acute attack of dyspnoea with signs of left ventricular failure; investigations showed cardiomegaly on chest $x$ ray picture, paroxysmal supraventricular tachycardia on electrocardiogram, and enlarged left ventricular cavity with hypokinetic septal motion on echocardiogram. Two other patients, aged 35 and 57 years, with myocarditis were dyspnoeic on exertion and experienced palpitations, with signs of subendocardial ischaemia on electrocardiogram and slightly enlarged left ventricular cavity and decreased ejection fraction on echocardiogram. No case of complete heart block was found.

Four of the anti-Ro positive patients with cardiac conduction defects or myocarditis had mild arterial hypertension (according to the WHO classification) and diffuse glomerulonephritis of various types confirmed by kidney biopsy. None of the eight patients had a history or ECG signs of angina pectoris or myocardial infarction. There were no HLA associations with myocarditis or cardiac conduction defects in adults with SLE (table 3).

\section{Discussion}

Our study showed a high percentage $(22 \%)$ of minor conduction defects or myocarditis in antiRo positive adult patients with SLE, compared
Table 3: HLA phenotypes in nine patients with systemic lupus enythematosus and myocarditis or cardiac conduction defects

\begin{tabular}{ll}
\hline Patient No & HLA markers \\
\hline 1 & A2 A9 B12 BX DR7 DRX DRw52 \\
2 & A2 AX B7 B44 DR1 DR8 \\
3 & A1 Aw19 B5 B8 DR3 DR7 \\
4 & A2 A24 B7 B15 DR2 DRw52 \\
5 & A1 A29 B8 B17 DR3 DR6 DRw52 \\
6 & A1 AX B5 Bw22 DR2 DR4 \\
7 & A2 A24 B7 B39 DR1 DR10 \\
8 & A1 A2 B8 BX DR3 DR8 DRw52 \\
9 & A2 AX B5 B39 DR4 DRX (DRw5 or DRw6)
\end{tabular}

with anti-Ro negative lupus patients $(p<0.01)$ and healthy controls $(p<0.01)$.

Cardiac disease is not uncommon in SLE $^{2}{ }^{16}{ }^{22-27}$ and includes pericarditis, myocarditis, conduction defects, valve lesions, and premature coronary atherosclerosis (sometimes thought to be a consequence of long term corticosteroid treatment). Myocardial disease was present in $42 \%$ of necropsies and a prolonged $P-R$ interval was present in $10 \%$ of patients with SLE in a study by Ropes. ${ }^{28}$

Neonatal lupus erythematosus was first described by McCuiston and Schoch in $1954 .^{4}$ Since then the connection between congenital complete heart block and autoantibodies to Ro and La antigens has been described in several studies. $^{6-12}$ The presence of Ro and La antigens in the nuclei of the myocardial cells and cells of the conduction system is supported by indirect immunofluorescence tests. ${ }^{11}$ 29-32 The mechanism of congenital heart block presumably entails transplacental passage of maternal antibodies. ${ }^{33}$ The damage to the myocardial and cardiac conduction system cells might be caused by a direct cytotoxic effect of anti-Ro or possibly anti-La antibodies. ${ }^{6} 1229$ It is unlikely that antibody enters cells, but antigen might be expressed on the cell membrane (perhaps in response to virus infection). Cardiac tissue injury might follow the influx of inflammatory cells once autoantibodies have bound to tissue and complement has been activated. ${ }^{29}$

Complete heart block was not found in any of our 36 anti-Ro positive patients, but Maier reported one patient with anti-Ro antibody in whom complete heart block was the first manifestation of SLE. ${ }^{13}$ Provost suggested that expression of Ro antigen is more pronounced in the fetal heart, but membrane expression may be the relevant factor. ${ }^{35}$

Our results indicate that anti-Ro antibody

Table 2: Myocarditis or cardiac conduction defects in 67 patients with systemic lupus erythematosus

\begin{tabular}{|c|c|c|c|c|c|c|}
\hline Patient No & $\begin{array}{l}\text { Age } \\
\text { (years) } \\
\text { and sex }\end{array}$ & $\begin{array}{l}\text { Follow up } \\
\text { (months) }\end{array}$ & Anti-Ro & $\begin{array}{l}\text { Other } \\
\text { anti-ENA* }\end{array}$ & Myocarditis & $\begin{array}{l}\text { Cardiac conduction } \\
\text { defects }\end{array}$ \\
\hline $\begin{array}{l}1 \\
2 \\
3 \\
4 \\
5 \\
6 \\
6 \\
7 \\
8 \\
9\end{array}$ & $\begin{array}{ll}17 & F \\
36 & F \\
49 & M \\
55 & F \\
62 & M \\
57 & F \\
39 & F \\
35 & F \\
35 & F\end{array}$ & $\begin{array}{r}7 \\
55 \\
96 \\
192 \\
120 \\
132 \\
27 \\
36 \\
6\end{array}$ & $\begin{array}{l}- \\
+ \\
+ \\
+ \\
+ \\
+ \\
+ \\
+ \\
+\end{array}$ & $\begin{array}{l}\text { PL-4 } \\
- \\
- \\
\text { nRNP } \\
- \\
+ \\
\text { La } \\
\text { La } \\
-\end{array}$ & $\begin{array}{l}- \\
- \\
- \\
+ \\
- \\
+ \\
- \\
+ \\
-\end{array}$ & $\begin{array}{l}\text { RBBB* } \\
\text { RBBB } \\
\text { AV I, }{ }^{*} \text { LAHB* } \\
\text { AV I, LAHB } \\
\text { AV I } \\
\overline{A V} \text { I, LAHB } \\
\overline{\text { RBBB }}\end{array}$ \\
\hline
\end{tabular}

*ENA=extractable nuclear antigens; RBBB=right bundle branch block; AV I=atrioventricular block, first grade; LAHB=left anterior hemiblock. 
might be a marker of cardiac injury in adult patients with SLE as Behan et al suggested it might be for polymyositis. ${ }^{36}$ They found that the appearance of antibodies to Ro antigen in patients with polymyositis and heart lesions, including conduction defects, was about 700fold more common than in the normal population. There was a fairly high number of patients with complete heart block and polymyositis (five of 55) in Behan's series compared with the results of our study on adult patients with SLE. We cannot account for this discrepancy.

Recent work distinguishes two types of Ro antigen, and congenital heart block is now thought to be associated with antibody to the smaller form of Ro and with anti-La. ${ }^{34} 37$ It will be interesting to extend these findings to the cardiac defects of adults with lupus, in whom anti-Ro, and not anti-La, is the principal factor.

We thank Dr Robert M Bernstein, Manchester Royal Infirmary, for his kind gift of sera to the PCNA, SL, and PL-4 antigens, and for his helpful comments.

This study was supported by the Slovene Research Council.

1 Maddison PJ, Mogavero H, Provost T T. The clinical significance of autoantibodies to a soluble cyto-plasmatic significance of autoantibodies to a soluble cyto-plasmatic antigen in systemic lupus erythematosus and other co

2 Reichlin M. Clinical and immunological significance of antibodies to $\mathrm{Ro}$ and $\mathrm{La}$ in systemic lupus erythematosus. Arthritis Rheum 1982; 25: 767-72.

3 Sontheimer R D, Stastny P, Maddison P. Anti-Ro and La antibodies and further HLA association in subacute cutaneous lupus erythematosus (SCLE). Arthritis Rheum 1980; 23: 750 .

4 McCuiston C H, Schoch E P. Possible discoid lupus erythematosus in newborn infants. Arch Dermatol 1954; 70: 782-5.

5 Barber $\dot{K}$ A, Jackson R. Neonatal lupus erythematosus: five new cases with HLA typing. Can Med Assoc $\mathcal{F}$ 1983; 129: $139-41$.

6 Buyon J P, Steven H S, Harold E F, Frederick Z B, Robert $J$ W. Intrauterine therapy for presumptive fetal myocarditis with acquired heart block due to systemic lupus erythematosus. Experience in a mother with a predominance of SS-B (La) antibodies. Arthritis Rheum 1987; 30: 44-9.

7 Buyon J, Szer I. Passively acquired autoimmunity and the maternal fetal death in SLE. In: Seminars in immunopathology. New York: Springer, 1988.

8 Carter J B, Blieden L C, Edwards J E. Congenital heart block: anatomic correlations and review of literature. Archives of Pathology 1974; 97: 51-7.

9 Chameides L, Trnuex R C, Vetter V, Rashkind V J, Galioto F M, Noonan J A. Maternal systemic lupus erythematosus and congenital complete heart block. $N$ Engl $₹$ Med 1977; 297: 1204-7.

10 Kephart D C, Hood A F, Provost T T. Neonatal lupus erythematosus: new serologic findings. $\mathcal{f}$ Invest Dermatol 1981; 77: 331-3.

11 Litsey S E, Noonan J A, O'Connor W N, Cottrill C M, Mitchell B. Maternal connective tissue disease and congenital heart block: demonstration of immunoglobulin in cardiac tissue. N Engl f Med 1985; 312: 98-100.

12 Lockshin M D, Gibofsky A, Peebles C L, Gigli J, Fortino M, Hurwitz S. Neonatal lupus erythematosus with heart block: family study of a patient with anti SS-A and SS-B antibodies. Arthritis Rheum 1983; 26: 210-3.
13 Maier W P, Ramirez H E, Miller S B. Complete heart block as an initial manifestation of systemic lupus erythematosus. Arch Intern Med 1987; 147: 170-1.

14 Tan E M, Cohen A S, Fries J F, et al. The 1982 revised criteria for the classification of systemic lupus erythematosus. Arthritis Rhewm 1982; 25: 1271-7.

15 Wynne J, Braunwald E. The cardiomyopathies and myocarditis. In: Braunwald E, ed. Heart disease. Philadelphia: Saunders, 1984: 1399-456.

16 Borenstein D G, Fye W B, Arnett F C. The myocarditis of systemic lupus erythematosus. Ann Intern Med 1978; 89: 619-24.

17 French $W S$, Crilley $J M$. Caution in the diagnosis and treatment of myocarditis. Am $\mathcal{F}$ Cardiol 1984; 54: 445-6.

18 Pincus T. Immunochemical conditions affecting the measurement of DNA antibodies using ammonium sulfate precipitation. Arthritis $R$ hewom 1971; 14: 623-30.

19 Bunn C C, Gharavi G R V. Antibodies to extractable nuclear antigens in 173 patients with DNA binding positive SLE an association between antibodies to ribonucleoprotein and Sm antigens observed by counterimmunoelectrophoresis. f Clin Lab Imomunol 1982; 8: 13-17.

20 Terasaki P, McClelland J D. Microdroplet assay of human cytotoxins. Nature 1964; 204: 998-1000.

21 Lowry R, Goguen J, Carpenter C B, Strom T B, Garovoy M R. Improved B cell typing for HLA-DR using nylon $M$ R. Improved B cell typing for HLA-DR using nylon
wool column enriched B lymphocyte preparations. Tissue wool column enriched B lym

22 Bonfiglio T A, Botti R E, Hagstron J W C. Coronary arteritis occlusion and myocardial infarction due to lupus erythematosus. Am Heart f 1972; 83: 153-8.

23 Chia G L, Mah E P K, Feng P H. Cardiovascular abnormalities in systemic lupus erythematosus. $\mathscr{F} C U 1981$ 9: $237-41$.

24 Gross $L$. The cardiac lesions in Libman-Sacks disease with consideration of its relationship to acute diffuse lupus erythematosus. Am f Pathol 1940; 16: 375-408.

25 Paget J A. Mitral valve disease of systemic lupus erythematosus. A cause of severe congestive heart failure reversed by valve replacement. Am $\mathcal{J}$ Med 1975; 59: 134-9.

26 Stollerman G H. Rheumatic and heritable connective tissue diseases of the cardiovascular system. In: Braunwald E, ed. Heart disease. Philadelphia: Saunders, 1984: 1641-75.

27 Weisz S, Young D G. Myocardial abscess complicating healed myocardial infarction. Can Med Assoc $\mathcal{F}$ 1977; 116 : 1156-8.

28 Ropes M W. Systemic lupus erythematosus. Cambridge, MA: Harvard University Press, 1976.

29 Lee L A, Coulter S, Erner S, Chu H. Cardiac immunoglobulin deposition in congenital heart block associated with maternal anti-Ro autoantibodies. Am 7 Med 1987; 83: 793-6.

30 Taylor P V, Scott J S, Gerlis L M, Esscher E, Scott $\dot{O}_{\text {. }}$ Maternal antibodies against fetal cardiac antigens in congenital complete heart block. $N$ Engl $\mathcal{F}$ Med 1986; 315: 667-72.

31 Deng J S, Bair L W, Schwarz S S, Joldman R S, Mediger T, Jr. Localization of Ro (SS A) antigen in the cardiac conduction system. Arthritis Rheum 1987; 30: 1232-8.

32 Watson R M, Lane A T, Barnett N K, Bias W B, Arnett F C, Provost T T. Neonatal lupus erythematosus. A clinical, serological and immunogenetic study with review of the literature. Medicine (Baltimore) 1984; 63: 362-78.

33 Buyon J P, Ben-Chetrit E, Karp S, et al. Association of congenital complete heart block with maternal antibody response to the novel $52 \mathrm{kD}$ SSA/Ro. Arthritis Rheum 1989; 32: S104.

34 Silverman E D, Mamula M J, Hardin J A, Laxer R M. The association of the congenital heart block (CHB) of neonatal lupus erythematosus (NLE) and both anti-Ro and anti-La antibodies. Arthritis Rheum 1989; 32: S104.

35 Provost T T. Discussion. Clinical aspects of systemic lupus erythematosus: Part A. F Rheumatol 1987; 14: (suppl 13): S206.

36 Behan W M H, Behan P O, Gairns J. Cardiac damage in polymyositis associated with antibodies to tissue ribonucleoproteins. Br Heart $\mathcal{f} 1987$; 57: 176-80.

37 Buyon Y P, Pompeo L, Elkon K, Winchester R J, Lockshin $M$ D. Characterization, by immunoblot, of the immune response to SSA/Ro associated with congenital heart block. Arthritis Rhewm 1989; 32: S104. 